\title{
Osteopontin: A Novel Cytokine Involved in the Regulation of Mycobacterium avium subspecies paratuberculosis Infection in Periparturient Dairy Cattle
}

\author{
E. L. Karcher, ${ }^{*}$ D. O. Bayles, $\dagger$ J. P. Bannantine, $†$ D. C. Beitz, ${ }^{*}$ and J. R. Stabel ${ }^{1}$ \\ *Department of Animal Science, lowa State University, Ames 50011 \\ †USDA-ARS, National Animal Disease Center, Ames, IA 50010
}

\section{ABSTRACT}

Osteopontin (Opn), an important mediator of the cellmediated immune response, enhances the host immune response against mycobacterial infections. Infections caused by Mycobacterium avium ssp. paratuberculosis (MAP) have a devastating effect on the dairy industry. We sought to characterize Opn at the level of gene and protein expression in periparturient dairy cows naturally infected with MAP. Peripheral blood mononuclear cells (PBMC) were isolated from control, subclinical, and clinical periparturient dairy cows naturally infected with MAP beginning $3 \mathrm{wk}$ precalving to $5 \mathrm{wk}$ postcalving and incubated with medium alone (nonstimulated: NS), concanavalin A (ConA), or a wholecell sonicate of MAP (MPS). Real-time PCR was performed to evaluate expression of Opn and classical Th1 and Th2 cytokines. Results demonstrated greater Opn expression in nonstimulated PBMC isolated from subclinical cows compared with control and clinical cows. For clinical cows, there was a strong correlation between Opn expression and expression of the Th1 cytokines IFN- $\gamma$ and IL- $1 \alpha$ for nonstimulated PBMC and IFN- $\gamma$ and IL-12 for PBMC stimulated with MPS. Expression of tumor necrosis factor- $\alpha$ was greater in clinical cows than the other groups. Nonstimulated, ConA, and MPS-stimulated PBMC from subclinical cows secreted more IFN- $\gamma$, and MPS-stimulated PBMC from clinical cows secreted more IL-4 compared with the other groups. Immunoblot analysis of PBMC detected 4 Opn proteins at $60,52,34$, and $27 \mathrm{kDa}$. This is the first study to evaluate the role of Opn on the immune response of dairy cows naturally infected with MAP, and results suggest Opn may be a key regulator against MAP infection.

Key words: osteopontin, periparturient, Mycobacterium avium ssp. paratuberculosis

Received January 30, 2008.

Accepted April 6, 2008

${ }^{1}$ Corresponding author: judy.stabel@ars.usda.gov.

\section{INTRODUCTION}

The causative agent of Johne's disease (JD) in ruminant animals is Mycobacterium avium ssp. paratuberculosis (MAP). Dairy cows are generally infected as neonates by the ingestion of feed or water contaminated with the organism. Once they are infected, animals may remain in the subclinical or asymptomatic stage of disease until a period of stress, such as parturition, occurs. Advancement to the clinical stage of disease is characterized by fecal shedding of the bacteria, severe weight loss, and intermittent diarrhea. There are no known cures for JD, and often the animal will succumb to the infection.

Osteopontin (Opn), also identified as early T-cell activator-1, is a highly acidic glycoprotein that is produced by both immune and nonimmune cells, such as osteoclasts, smooth muscle cells, and epithelial cells (Denhardt and Guo, 1993). The primary immune sources of Opn are activated macrophages (Atkins et al., 1998), activated T cells (Ashkar et al., 2000), and dendritic cells (Kawamura et al., 2005). Osteopontin is also secreted from activated natural killer cells (Pollack et al., 1994), and it is an important modulator of the cellmediated, or Th1, immune response. Osteopontin induces T-cell chemotaxis and costimulates T-cell proliferation (O'Regan et al., 2000). Stimulating murine macrophages with Opn resulted in the production of proinflammatory cytokines IL-12 and tumor necrosis factor$\alpha$ (TNF- $\alpha$; Weber et al., 2002). In addition, when human gut-derived $\mathrm{T}$ cells were stimulated with bovine Opn and CD3 antibody, there was a dose-dependent increase in the secretion of IFN- $\gamma$ and TNF- $\alpha$ (Agnholt et al., 2007). In addition to its effects on T cells, Opn stimulates IgM and IgG production from B cells (Lampe et al., 1991).

The role of Opn in mycobacterial infection is interesting, because Opn is reported to upregulate and promote the expression and secretion of Th1 cytokines. When Opn knockout mice were challenged with Mycobacterium bovis bacillus Calmette-Guerin (BCG Pasteur), they had more severe infection, heavier bacterial loads, 
and greater granuloma burdens compared with the wild-type mice (Nau et al., 1999). Infecting human alveolar macrophages with Mycobacterium tuberculosis was accompanied by an upregulation of Opn expression (Nau et al., 1997). Furthermore, an inverse correlation has been noted between the amount of Opn in tissues and disease severity in patients with mycobacterial infections (Nau et al., 2000). Patients suffering from nontuberculous mycobacterial infections with high Opn protein levels in the lymph nodes recovered faster compared with those patients with lower Opn levels (Nau et al., 2000).

The ability of Opn to promote a Th1 immune response and increase resistance to mycobacterial infections makes this cytokine important to study in MAP-infected cattle. An effective Th1 response to MAP infection is critical for controlling the initial stages of the disease. Subclinical JD cows produce greater amounts of the Th1 cytokines IFN- $\gamma$ and TNF- $\alpha$ compared with clinical cows (Stabel, 2000). The transition from the subclinical to clinical stage of disease coincides with a shift from Th1- to Th2-mediated host responses. Production of Th2 cytokines supports a humoral immune response by stimulating the proliferation of B lymphocytes and inhibiting Th1 cytokines. Previous reports have demonstrated an upregulation of both IL-10 and transforming growth factor (TGF)- $\beta$ in the tissues of clinical MAP-infected cows (Khalifeh and Stabel, 2004).

To date, there are no reports in the literature of Opn expression in dairy cows infected with MAP. Based on this observation, and the critical role of Opn in controlling other mycobacterial infections, the objective of this study was to characterize Opn at both the level of gene and protein expression in periparturient dairy cows naturally infected with MAP. In addition, the expression and secretion of other key Th1 and Th2 cytokines was performed during this time period and correlated with Opn results.

\section{MATERIALS AND METHODS}

\section{Animals}

Twenty-five multiparous Holstein cows were placed into 3 groups according to infection status. These 3 groups consisted of 8 noninfected healthy cows, 10 cows naturally infected with MAP but asymptomatic, and 7 naturally infected cows with clinical JD. The stage of infection was determined by fecal shedding of MAP, IFN- $\gamma$ secretion, and specific antibody response to MAP. Infection was monitored by bacteriologic culture for the fecal shedding of MAP by standard methods (Stabel, 1997). By definition, clinical animals were shedding more than $100 \mathrm{cfu} /$ tube of media (BBL Herrold's Egg Yolk Agar Slants with mycobactin J, 2 mg/
$\mathrm{mL}$; amphotericin, $50 \mu \mathrm{g} / \mathrm{mL}$; nalidixic acid, $50 \mu \mathrm{g} / \mathrm{mL}$; and vancomycin, $50 \mu \mathrm{g} / \mathrm{mL}$; Becton, Dickinson and Co., Sparks, MD) and presented with weight loss and intermittent diarrhea. Subclinically infected cows were shedding less than $10 \mathrm{cfu} /$ tube and were asymptomatic. The noninfected control cows were characterized by repeated negative fecal cultures performed quarterly over a 3- to 5-yr period and had been purchased from herds with no recent history of JD. In addition, these animals were negative on any serologic assays (i.e., production of antibody specific for MAP and IFN- $\gamma$ ) performed during that period. All procedures performed on the animals were approved by the Institutional Animal Care and Use Committee (National Animal Disease Center, Ames, IA).

\section{Blood Collection, Culture Conditions, and Sample Collection}

Blood was collected from the jugular vein in $2 \times$ acidcitrate-dextrose (1:10). For each animal, blood was collected at $-21,-14,-7,+1,+7,+14,+21,+28$, and +35 $\mathrm{d}$ relative to calving. Peripheral blood mononuclear cells (PBMC) were isolated from the buffy coat fractions of peripheral blood. The PBMC were resuspended in RPMI-1640 (Gibco, Grand Island, NY) with 10\% fetal calf serum (Atlanta Biologics, Atlanta, GA), $100 \mathrm{U}$ of penicillin $\mathrm{G}$ sodium per milliliter, $100 \mu \mathrm{g}$ of streptomycin sulfate $/ \mathrm{mL}, 0.25 \mu \mathrm{g}$ of amphotericin $\mathrm{B} / \mathrm{mL}$, and 2 $\mathrm{m} M$ L-glutamine (Gibco). Cells were cultured at $1.4 \times$ $10^{6} / \mathrm{mL}$ in 48 -well flat-bottomed plates (Corning, Corning, NY) with either medium alone (nonstimulated; NS), with concanavalin A (ConA; $10 \mu \mathrm{g} / \mathrm{mL})$, or with MAP whole-cell sonicate (MPS; $10 \mu \mathrm{g} / \mathrm{mL}$ ) added to designated wells. Plates were incubated for $24 \mathrm{~h}$ at $39^{\circ} \mathrm{C}$ in $5 \% \mathrm{CO}_{2}$ in a humidified atmosphere. After $24 \mathrm{~h}$, plates were centrifuged at $400 \times g$ for $5 \mathrm{~min}$. Supernatants were removed without disturbing the cells in culture and stored at $-20^{\circ} \mathrm{C}$ before cytokine measurement.

\section{Bacteria}

Mycobacterium avium ssp. paratuberculosis strain K10 (National Animal Disease Center) was grown in Middlebrook 7H9 broth (pH 6.0) supplemented with mycobactin J (2 mg/L; Allied Monitor, Fayette, MO) and oleic acid-albumin-dextrose complex (Becton Dickinson Microbiology, San Jose, CA). The bacteria were harvested and washed 3 times with PBS ( $137 \mathrm{mM}$ sodium chloride, $10 \mathrm{~m} M$ phosphate, $2.7 \mathrm{~m} M$ potassium chloride; $\mathrm{pH}$ 7.4). The MPS was then prepared by sonication of MAP $\left(1 \times 10^{9} / \mathrm{mL}\right)$ in PBS at $25 \mathrm{~W}$ for 25 min on ice (Tekmar sonic disturber, Lorton, VA), and a protein concentration was determined. The MPS was diluted 
to a final concentration of $1 \mathrm{mg} / \mathrm{mL}$ and then stored at $-20^{\circ} \mathrm{C}$.

\section{RNA Extraction and Real-Time PCR}

Peripheral blood mononuclear cells from each of the sampling time points were resuspended in RPMI 1640 (Gibco) containing $10 \%$ fetal calf serum. The PBMC from each cow at each sampling time point were split into 2 aliquots: 1 aliquot that was cultured with medium alone (NS) and 1 that was stimulated with MPS (10 $\mu \mathrm{g} / \mathrm{mL}$ ). Cells were cultured in $75-\mathrm{cm}^{2}$ flasks at a concentration of $1 \times 10^{7} \mathrm{PBMC}$ per flask at $39^{\circ} \mathrm{C}$ in $5 \% \mathrm{CO}_{2}$ in a humidified atmosphere for $24 \mathrm{~h}$. Ribonucleic acid was extracted from NS- and MPS-stimulated PBMC by using the standard protocol for Trizol Reagent (Invitrogen Life Technologies Corp., Carlsbad, CA). All RNA samples were purified by using the RNeasy Mini Kit Protocol for RNA Cleanup (Qiagen, Valencia, CA). Samples were treated with TURBO DNA-free (Ambion, Austin, TX). The quantity of total RNA was determined by UV spectrophotometry (NanoDrop ND-1000 Spectrophotometer, Thermo Fisher Scientific, Pittsburgh, PA). The RNA samples were frozen at $-80^{\circ} \mathrm{C}$ until converted to cDNA.

Total RNA extracted from both NS- and MPS-stimulated cells was converted to first-strand cDNA. Briefly, $2 \mu \mathrm{g}$ of total RNA was added to each $12-\mu \mathrm{L}$ reaction mixture consisting of $10 \mathrm{~m} M$ oligo(dT) ${ }_{12-18}$ primer (Invitrogen) and RNase-free water. The reaction mixture was incubated at $70^{\circ} \mathrm{C}$ for $5 \mathrm{~min}$ and then quickly chilled on ice to $20^{\circ} \mathrm{C}$. To the reaction mixture, $4 \mu \mathrm{L}$ of $5 \times$ First Strand Buffer (Invitrogen), $2 \mu \mathrm{L}$ of $10 \mathrm{~m} M$ dNTP Mix (Invitrogen), $1 \mu \mathrm{L}$ of $0.1 \mathrm{M}$ dithiothreitol (Invitrogen), and $2 \mathrm{U}$ of SuperScript RNase H-Reverse Transcriptase (Invitrogen) were added for a total volume of $20 \mu \mathrm{L}$. The reaction mixture was incubated at $42^{\circ} \mathrm{C}$ for $1 \mathrm{~h}$, heated to $70^{\circ} \mathrm{C}$ for $15 \mathrm{~min}$, and then cooled to $37^{\circ} \mathrm{C}$. Two units of DNase-free RNase H (Invitrogen) were added, and the mixture was incubated at $37^{\circ} \mathrm{C}$ for 20 min to remove the original RNA template. The RNase $\mathrm{H}$ was inactivated by heating the reaction mixture at $70^{\circ} \mathrm{C}$ for $10 \mathrm{~min}$. All cDNA samples were stored at $-80^{\circ} \mathrm{C}$ until real-time PCR (RT-PCR) analyses were performed.

Real time RT-PCR was performed by using an Applied Biosystems 7500 DNA sequence detection system (Perkin-Elmer Corp., Foster City, CA). SYBR Green PCR master mixture (Perkin-Elmer Corp.), template cDNA, and gene-specific primers for Opn, IFN- $\gamma$, TNF$\alpha$, IL-1 $\alpha$, IL-12p35, IL-4, IL-10, TGF- $\beta 1$, and $\beta$-actin were combined in a $20-\mu \mathrm{L}$ reaction mixture. Primer sequences are listed in Table 1 . All reactions were performed in triplicate. There were a total of 12,150 RT-
Table 1. Primers used for PCR of bovine cytokine gene transcripts

\begin{tabular}{lcl}
\hline Gene & Primer $^{1}$ & Sequence \\
\hline$\beta$-actin & $\mathrm{F}$ & CGCCATGGATGATGATATTGC \\
$\beta$-actin & $\mathrm{R}$ & AAGCCGGCCTTGCACAT \\
IFN- $\gamma$ & $\mathrm{F}$ & TGGAGGACTTCAAAAAGCTGATT \\
IFN- $\gamma$ & $\mathrm{R}$ & TTTATGGCTTTGCGCTGGAT \\
IL-1 $\alpha$ & $\mathrm{F}$ & TTGGTGCACATGGCAAGTG \\
IL-1 $\alpha$ & $\mathrm{R}$ & GCACAGTCAAGGCTATTTTTCA \\
IL-4 & $\mathrm{F}$ & GCCACACGTGCTTGAACAAA \\
IL-4 & $\mathrm{R}$ & TGCTTGCCAAGCTGTTGAGA \\
IL-10 & $\mathrm{F}$ & GCCTTGTCGGAAATGATCCA \\
IL-10 & $\mathrm{R}$ & TCAGGCCCGTGGTTCTCA \\
IL-12p35 & $\mathrm{F}$ & CTTTCTTCAAATGCAGCATTGG \\
IL-12p35 & $\mathrm{R}$ & GGGTCTGGGTGATACAACGAA \\
Opn & $\mathrm{F}$ & ACAGCCAGGACGTCAACTCT \\
Opn & $\mathrm{R}$ & GTGAGACTCGTCGGAATGGT \\
TGF- $-\beta 1^{2}$ & $\mathrm{~F}$ & AACAATTCCTGGCGCTACCTC \\
TGF- $\beta 1^{2}$ & $\mathrm{R}$ & TGCCGCACAACTCCAGTG \\
TNF- $\alpha$ & $\mathrm{F}$ & TCTACCAGGGAGGAGTCTTCCA \\
TNF- $\alpha$ & $\mathrm{R}$ & GTCCGGCAGGTTGATCTCA \\
\hline
\end{tabular}

${ }^{1} \mathrm{~F}=$ forward; $\mathrm{R}=$ reverse.

${ }^{2}$ Liang et al., 2008.

PCR reactions performed in this study. This number represents 25 cows, 9 sampling time points, 9 genes of interest, 3 replications of each gene within a time point and within a cow, and 2 stimulation states (NS or MPS). The $\beta$-actin gene was used as the control (for calculation of cycle threshold, dCt). Dissociation curves for each primer set were run to confirm a single peak and to ensure that no primer-dimers could be detected. Additionally, product size was evaluated using agarose gel electrophoresis. The RT-PCR data were analyzed by using the $2^{-(\mathrm{dd} C t)}$ method as described previously (Livak and Schmittgen, 2001). The $+1 \mathrm{dCt}$ value for each cow was used as the reference expression point.

\section{Measurement of IFN- $\gamma$, IL-10, TGF- $\beta$, and IL-4 Production in Cell Culture Supernatants by ELISA}

Bovine IFN- $\gamma$ was measured by using the Bovigam test kit (Biocor Animal Health, Omaha, NE) as described by the manufacturer. The minimal sample concentration of IFN- $\gamma$ that could be detected by using the kit was $0.39 \mathrm{ng} / \mathrm{mL}$.

Bovine IL-10 was quantified by coating MaxiSorp microtiter plates (Nunc, Rochester, NY) with mouse antibovine IL-10 in coating buffer ( $15 \mathrm{~m} M$ sodium carbonate, $34 \mathrm{mM}$ sodium bicarbonate; $\mathrm{pH} 9.6 ; 100 \mu \mathrm{L}$ per well at $2 \mu \mathrm{g} / \mathrm{mL}$; MCA2110, Serotec, Raleigh, NC) overnight at room temperature. Plates were washed 5 times with PBS containing 1\% Tween 80 (washing buffer). The samples and serial 2-fold dilutions of bovine IL-10 standard $(0.3125$ to 20 units $/ \mathrm{mL}$; generous gift from Jayne Hope, Institute for Animal Health, Compton, UK) were added to duplicate wells and incubated at room temperature for $1 \mathrm{~h}$. Plates were then washed 5 
times with washing buffer before incubating with the detection antibody, mouse anti-bovine IL-10:biotin (MCA2111B, Serotec). Plates were washed 5 times with washing buffer, $100 \mu \mathrm{L}$ of avidin-HRP conjugate (diluted 1:800; PharMingen, San Diego, CA) was added to each well, and the plates were incubated for $45 \mathrm{~min}$ at room temperature. After another wash cycle, plates were incubated with substrate solution [ $40 \mathrm{mM} 2,2^{\prime}$ azino-di-ethylbenzthiozoline-6-sulfonic acid in citrate buffer (50 mM, pH 4.0) and $\mathrm{H}_{2} \mathrm{O}_{2}(30 \%$ solution as $1: 30$ dilution)]. Color development was quantified after 30 min by measuring absorbance at $405 \mathrm{~nm}$ with a Wallac Victor 1420 multilabel counter ELISA plate reader (Perkin-Elmer, Gaithersburg, MD). The minimal sample concentration of IL-10 that could be detected by using the kit was 0.3125 units.

Bovine TGF- $\beta$ was quantified using the Quantikine Human TGF- $\beta 1$ Immunoassay Kit as described by the manufacturer and by using standards supplied (R\&D Systems Inc., Minneapolis, MN). Significant concentrations of latent TGF- $\beta 1$ are found in bovine cell culture supernatants. Latent TGF- $\beta$ was activated by the addition of $1 \mathrm{~N} \mathrm{HCl}$ followed by $10 \mathrm{~min}$ of incubation. The samples were neutralized by the addition of $1.2 \mathrm{~N}$ $\mathrm{NaOH} / 0.5 M$ HEPES. The concentration determined by the standard curve was multiplied by the dilution factor 1.4 to account for the activation procedure. Because of the high cost of the kit and large number of samples in this study, only NS- and MPS-stimulated cell culture supernatants were evaluated at $-21,-14,-7,+1$, $+7,+14$, and $+21 \mathrm{~d}$ relative to calving for this assay. The minimal sample concentration of TGF- $\beta$ that could be detected by using the kit was $31.2 \mathrm{pg} / \mathrm{mL}$. Bovine IL-4 was measured using Bovine IL-4 Screen Set as described by the manufacturer and using standards supplied (Endogen, Rockford, IL).

\section{Protein Extraction and Immunoblots}

Peripheral blood mononuclear cells were isolated from whole blood and stored at $-80^{\circ} \mathrm{C}$ until protein extraction. At the time of extraction, a PBMC cell pellet was thawed on ice, and $1 \mathrm{~mL}$ of protein extraction buffer [Tris ${ }^{\mathrm{a}}$ EDTA (pH, 8.0), $50 \mathrm{mM} \mathrm{KCl,} 1 \mathrm{mg}$ of Protease Inhibitor Cocktail/mL (Sigma, St. Louis, MO)] was added. The sample was then sonicated at $25 \mathrm{~W}$ for 30 $\mathrm{s}$ with a Tekmar sonic disturber and incubated on ice for $10 \mathrm{~min}$. Sample was then centrifuged at 2,500 $\times g$ for $20 \mathrm{~min}$ at $4^{\circ} \mathrm{C}$, and the supernatant was transferred to a 1.5-mL microcentrifuge tube. Protein was quantified by using the BCA Protein Assay Reagent Kit (Pierce).

Protein samples were incubated at $95^{\circ} \mathrm{C}$ for $5 \mathrm{~min}$ and separated (16 $\mu \mathrm{g}$ of protein per lane) by 4 to $20 \%$
SDS-PAGE (Laemmli, 1970). The separated proteins were electrotransferred to a $0.45-\mu \mathrm{m}$ pure nitrocellulose membrane. For analysis of Opn and $\beta$-actin proteins, the membrane was blocked by overnight incubation in PBS plus $2 \%$ BSA and $0.1 \%$ Tween 20 (PBSBSA). The membrane was then incubated at room temperature for $2 \mathrm{~h}$ in PBS-BSA containing a polyclonal anti-mouse Opn antibody (1:2,500 dilution; Cosmo Bio Co. Ltd., Tokyo, Japan). After 3 washes in PBS plus $0.1 \%$ Tween 20 (PBST), blots were incubated for $1.5 \mathrm{~h}$ in protein A-peroxidase (1:20,000 dilution; Pierce). The blots were again washed 3 times as described above and were developed for chemiluminescence by using Supersignal detection reagents (Pierce). The membranes were blotted gently, wrapped in plastic wrap, and exposed to x-ray film (Kodak X-Omat AR, Rochester, NY). Membranes were then stripped by incubating in Restore Western Blot Blocking Stripping Buffer (Pierce) for $15 \mathrm{~min}$ at room temperature and then washing $3 \times$ for 5 min each in PBST. To ensure that the membrane had been completely stripped, the membrane was exposed to x-ray film (Kodak X-Omat AR). Membranes were then blocked by overnight incubation in PBS plus 2\% PBS-BSA and the following day were reprobed for $\beta$-actin (1:2,500 dilution; Imgenex, San Diego, CA).

\section{Determination of Molecular Size and Relative Protein Abundance}

Digital images of the autoradiographic film from the immunoblots were scanned, and scanning densitometry was performed with the Kodak Digital Science 1-D Image Analysis Software. Relative molecular weight of Opn and $\beta$-actin protein was calculated by regressing the distance of migration of the protein through the gel, against the relative molecular weights of known markers, ranging from 20.9 to $101 \mathrm{kDa}$ (prestained SDS-PAGE standards, low range; BioRad, San Diego, CA).

\section{Statistical Analysis}

The RT-PCR data were analyzed by using the $2^{-(\mathrm{ddCt})}$ method as described previously (Livak and Schmittgen, $2001)$. The $\beta$-actin was used as the reference gene, and the $\mathrm{dCt}$ value at $+1 \mathrm{~d}$ for each animal was used as the reference expression point. Outliers were determined by the SAS/STAT PROC RobustReg software (SAS Institute Inc., Cary, NC). To evaluate the appropriateness of $\beta$-actin as a reference gene, the $2^{-(\mathrm{dCt})}$ method was used as described previously (Schmittgen and Zakrajsek, 2000). This test indicated that $\beta$-actin would serve as a suitable reference for both healthy and MAP-infected animals. 
Several 2-factor repeated-measures analyses of variance were performed (one for each stimulation levelgene combination) comparing fold expression of the treatments through time. Levene's homogeneity of variance test was performed on data to determine transformation necessity. All analyses were performed on transformed data where necessary, but raw data means are presented for ease of interpretation. If a significant Ftest value from the ANOVA was obtained at $P \leq 0.05$, differences of least squares means were used as the pairwise multiple comparison test for determining day or infection group $\times$ day differences. Means differed if $P<0.05$ and tended to differ if $0.05 \leq P \leq 0.10$. Analyses were performed using PROC MIXED in SAS PC Windows Version 9.1.3 software. Pearson correlation coefficients were obtained using the PROC CORR procedure of SAS.

\section{RESULTS}

\section{Opn Gene Expression}

Overall, expression of Opn from NS PBMC was greater $(P<0.05)$ in subclinically infected animals compared with control and clinical cows (Figure 1A). There was also a significant interaction of infection group and parturition $(P<0.01)$. For the subclinical cows, Opn expression increased during the postpartum period and was significantly greater $(P<0.05)$ at $+14,+28$, and $+35 \mathrm{~d}$ compared with $+1 \mathrm{~d}$. Osteopontin expression in NS PBMC was reduced 7.7-fold between -21 and $+1 \mathrm{~d}$ $(P<0.001)$ in control cows and 6.9 -fold between $-7 \mathrm{~d}$ and $+1 \mathrm{~d}(P<0.01)$ in clinical cows.

When PBMC were stimulated with MPS, control cows expressed more Opn than subclinically $(P<0.001)$ and clinically $(P<0.05)$ infected cows (Figure 1B). For subclinical cows, expression increased $(P<0.001)$ at calving and then declined during the postpartum period. In contrast, a decline $(P<0.03)$ in Opn expression by MPSstimulated PBMC was observed for clinical cows as calving approached followed by an increase during the postpartum period.

\section{Effect of Infection Status on Th1 and Th2 Cytokine Gene Expression}

Overall, expression of the genes coding for the Th1 cytokines, IFN- $\gamma$, IL-12p35, IL- $1 \alpha$, for both NS- and MPS-stimulated PBMC was not different between animals of the different infection groups. The expression of TNF- $\alpha$ by NS PBMC was significantly increased in clinical cows $(6.39 \pm 1.2)$ compared with control $(2.19 \pm$ $1.0 ; P<0.02)$ and subclinical cows $(1.86 \pm 0.9 ; P<0.001$; Figure 2A). There was no effect of infection on TNF- $\alpha$ from MPS-stimulated PBMC (Figure 2B). The NS
A.

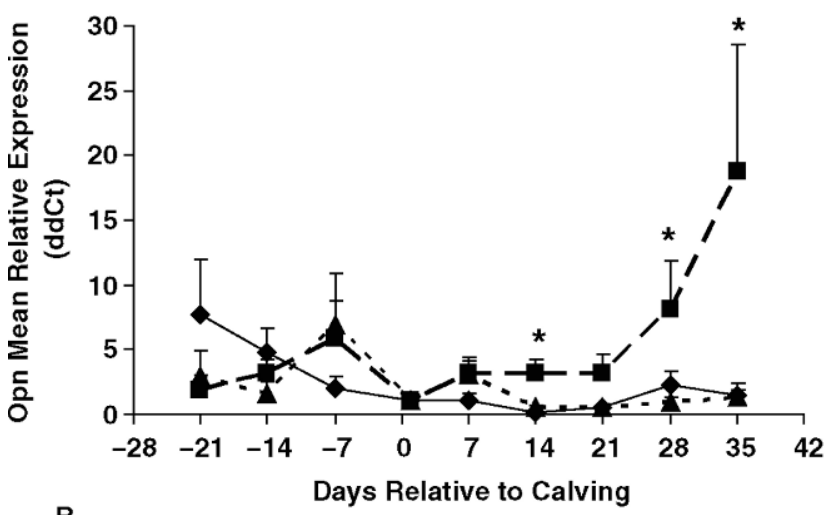

B.

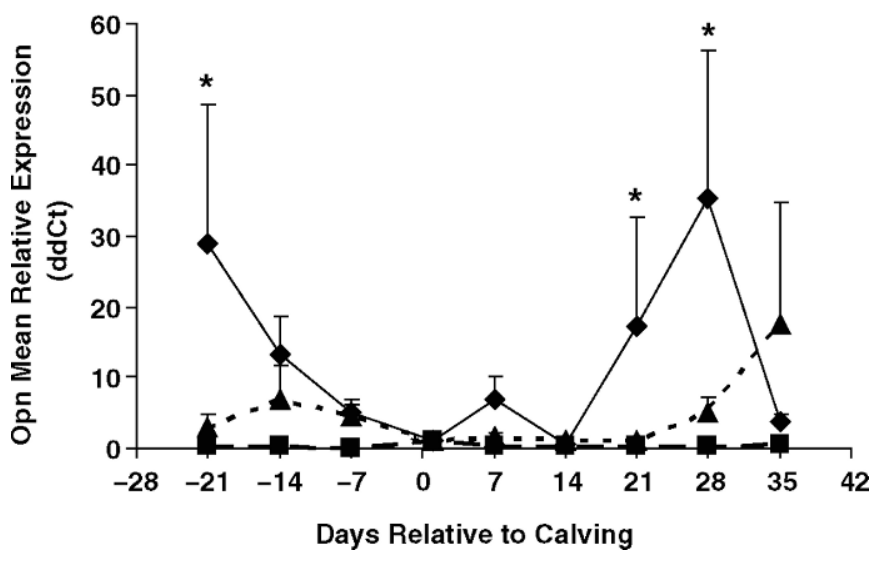

Figure 1. Osteopontin (Opn) gene expression by peripheral blood mononuclear cells (PBMC) isolated from whole blood of control ( $\bullet$ ),

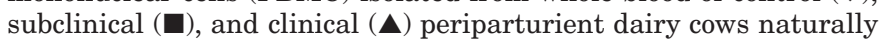
infected with Mycobacterium avium ssp. paratuberculosis (MAP). A) Nonstimulated PBMC (infection group, $P<0.05$; infection group $\times$ parturition, $P<0.05$ ). B) Peripheral blood mononuclear cells stimulated with a whole-cell sonicate of MAP (infection group, $P<0.05$ ). Data are means \pm SE. Significant differences within an infection group on a given day relative to $+1 \mathrm{~d}$ are represented by asterisks $(P<0.05)$.

PBMC from control cows tended to express more IL- $1 \alpha$ $(P<0.10)$ compared with infected cows (Figure $2 \mathrm{C})$. In contrast, after stimulation with MPS, there was a tendency for PBMC isolated from subclinical cows to express more IL- $1 \alpha$ compared with control cows (Figure 2D).

There was no overall effect of infection on the expression of the genes coding for the Th2 cytokines, IL-4 and IL-10. However, MPS-stimulated PBMC from control cows expressed more IL-4 than subclinical cows $(P<$ $0.05)$ and tended to express more than clinical cows $(P$ $<0.09$; Figure 3A). There was no effect of infection group or parturition on the expression of IL-4 by NS PBMC (data not shown). The expression of IL-10 from NS PBMC tended to be greater $(P<0.10)$ for control cows compared with clinical cows (Figure 3B), whereas MPS- 

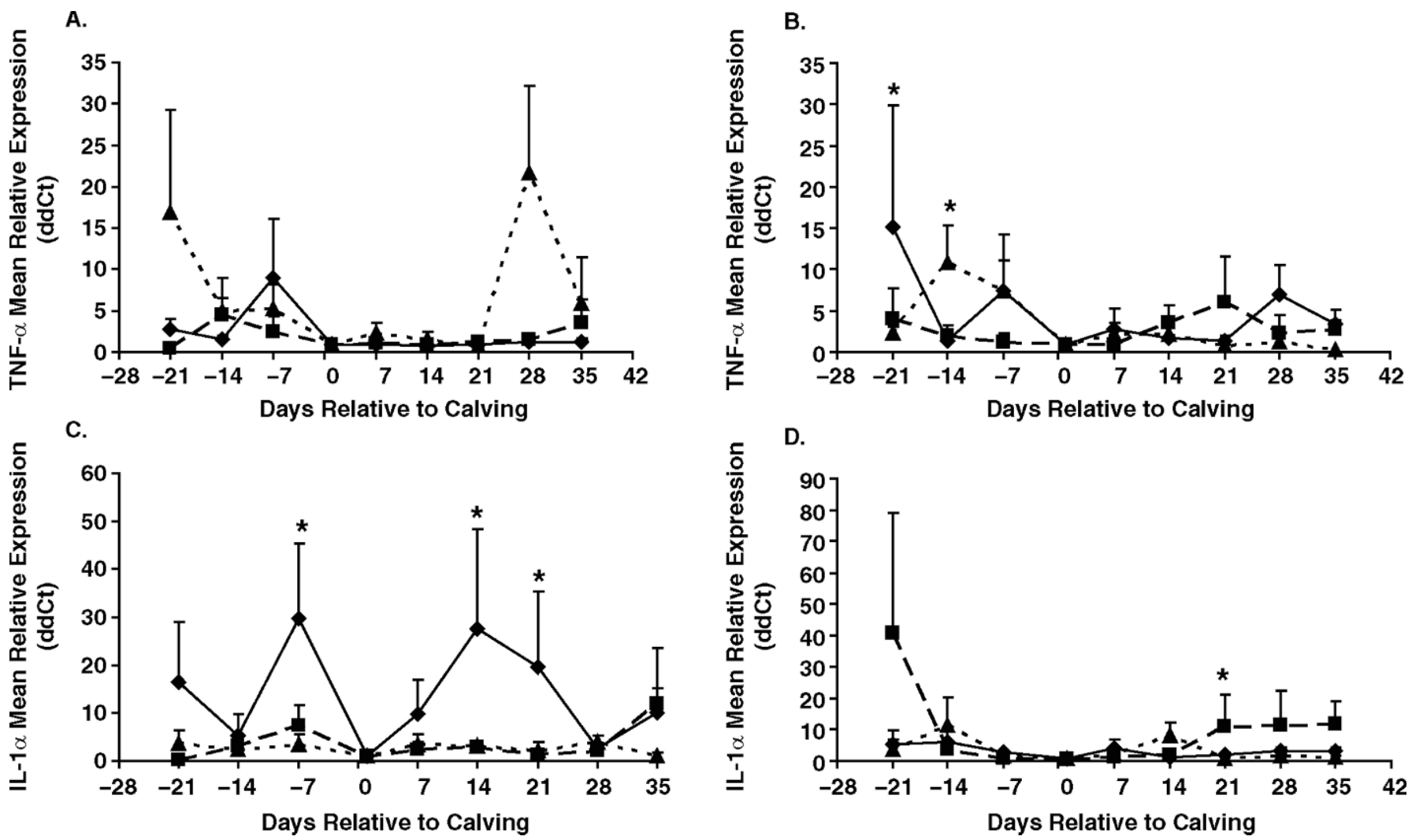

Figure 2. Expression of Th1 cytokines by peripheral blood mononuclear cells (PBMC) isolated from whole blood of control ( $)$, subclinical (ם), and clinical ( $\mathbf{\Delta}$ ) periparturient dairy cows naturally infected with Mycobacterium avium ssp. paratuberculosis (MAP). A) Tumor necrosis factor- $\alpha$ nonstimulated PBMC (NS PBMC; infection group, $P<0.05$; parturition, $P<0.05$ ). B) Tumor necrosis factor- $\alpha$ PBMC stimulated with a whole-cell sonicate of MAP (MPS PBMC). C) Interleukin- $1 \alpha$ NS PBMC. D) Interleukin-1 $\alpha$ MPS PBMC. Data are means \pm SE. Significant differences within an infection group on a given day relative to $+1 \mathrm{~d}$ are represented by asterisks $(P<0.05)$.

stimulated PBMC from clinical cows expressed more $(P<0.05)$ IL-10 compared with control and subclinical cows (Figure 3C). Overall, the expression of TGF- $\beta 1$ from NS PBMC was greater for clinical cows compared with control $(P<0.01)$ and subclinical cows $(P<0.05$; Figure 3D). Stimulating the cells with MPS resulted in PBMC from control and clinical cows $(P<0.05)$ expressing more TGF- $\beta 1$ than the subclinically infected animals (data not shown).

\section{Effect of Parturition on Th1 and Th2 Cytokine Gene Expression}

There was no effect of parturition on expression of genes coding for IL-12p35 or IL- $1 \alpha$ for NS and MPS PBMC. There was an overall effect of parturition $(P<$ 0.01 ) on the expression of IFN- $\gamma$ from NS PBMC (Figure 4). Expression by clinical cows declined $(P<0.01)$ from $-7 \mathrm{~d}$ to $+21 \mathrm{~d}$ with a brief rebound by $+28 \mathrm{~d}(P<0.01)$. Interferon expression by subclinical cows decreased $(P$ $<0.06)$ from $-7 \mathrm{~d}$ to calving. There was also a significant effect of parturition $(P<0.01)$ on expression of TNF- $\alpha$ by NS PBMC (Figure 2A). Control cows experienced a decline $(P<0.05)$ in TNF- $\alpha$ expression during the last week of the prepartum period. Expression for NS PBMC from clinical cows declined $(P<0.001)$ from $-21 \mathrm{~d}$ to +21 $\mathrm{d}$, with a rapid increase $(P<0.001)$ at $+28 \mathrm{~d}$. Similarly, expression of TNF- $\alpha$ by MPS-stimulated PBMC declined $(P<0.04)$ in clinical cows from $-14 \mathrm{~d}$ to $+1 \mathrm{~d}$ (Figure 2B).

There was no overall effect of parturition on the expression of IL-4 or IL-10 by NS- or MPS-stimulated PBMC. However, expression of IL-10 by NS PBMC isolated from control cows declined $(P<0.02)$ from $-21 \mathrm{~d}$ to $+1 \mathrm{~d}$ and then increased $(P<0.02)$ to $+35 \mathrm{~d}$ (Figure $3 \mathrm{~B})$. There was a trend for an overall effect of parturition on the expression of TGF- $\beta 1(P<0.08)$. The expression of TGF- $\beta 1$ by PBMC from clinical cows declined during the week before parturition $(P<0.01)$ and then increased during the postpartum period for the remaining sampling time points $(P<0.001$; Figure $3 \mathrm{D})$. Transforming growth factor- $\beta 1$ expression by PBMC isolated from control and clinical cows and stimulated 
A.
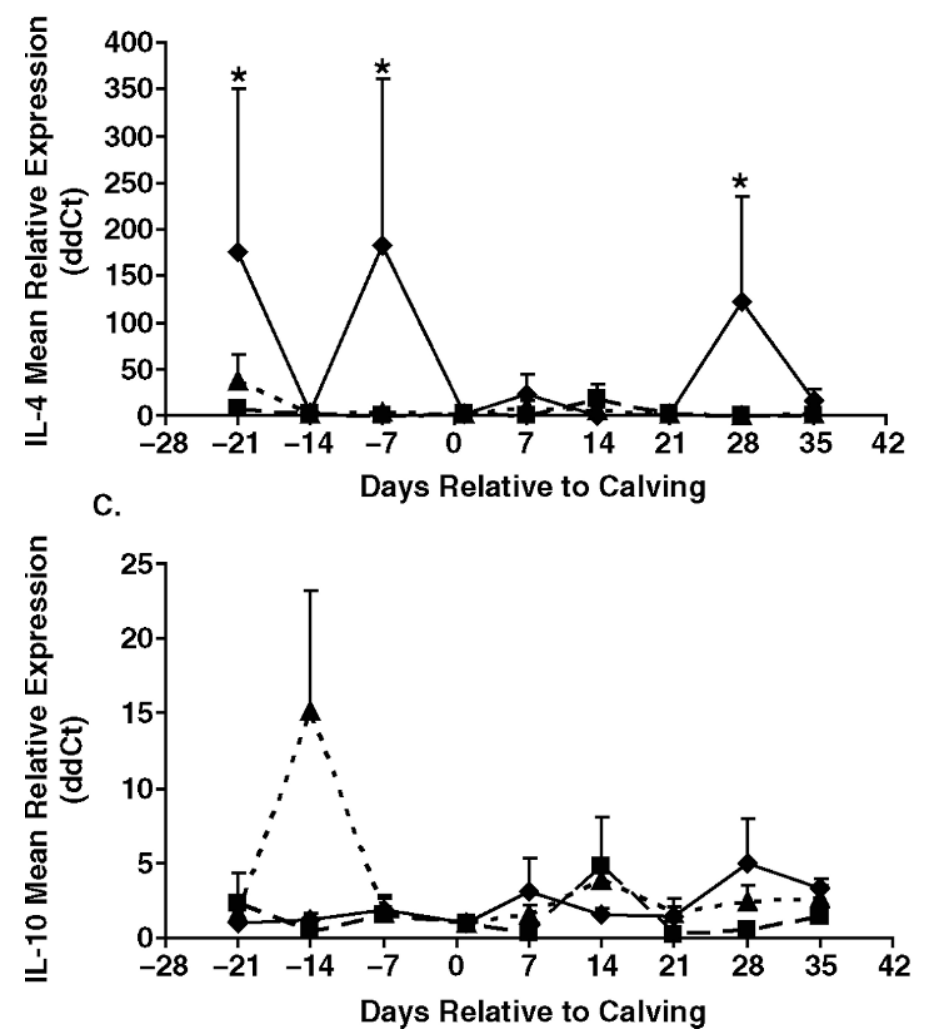

B.
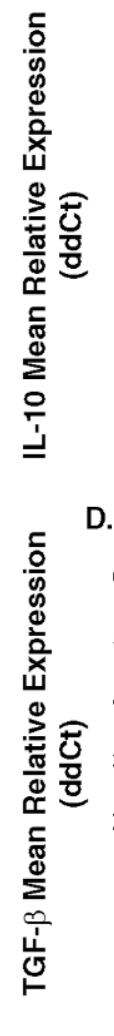

D.
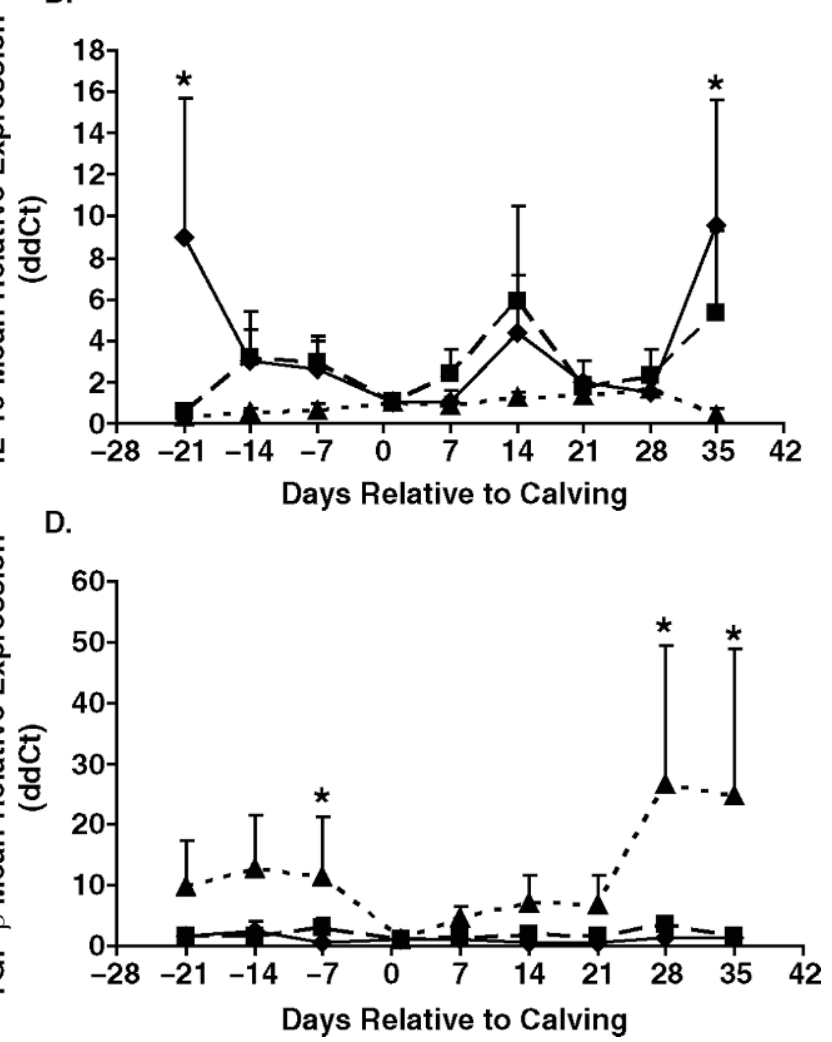

Figure 3. Expression of Th2 cytokines by peripheral blood mononuclear cells (PBMC) isolated from whole blood of control ( $\bullet$ ), subclinical (Ш), and clinical (山) periparturient dairy cows naturally infected with Mycobacterium avium ssp. paratuberculosis (MAP). A) Interleukin4 PBMC stimulated with a whole-cell sonicate of MAP (MPS PBMC). B) Interleukin-10 nonstimulated PBMC (NS PBMC). C) Interleukin10 MPS PBMC. D) Transforming growth factor- $\beta$ (TGF- $\beta$ ) NS PBMC (infection group, $P<0.05$ ). Data are means \pm SE. Significant differences within an infection group on a given day relative to $+1 \mathrm{~d}$ are represented by asterisks $(P<0.05)$.

with MPS declined beginning on $-21 \mathrm{~d}$ and continued to decline until parturition $(P<0.05$; data not shown).

\section{Pearson Correlation Coefficients for Opn mRNA}

The Pearson correlation coefficients for Opn mRNA in NS-stimulated PBMC isolated from clinically infected cows was $0.53(P<0.0003)$ for IFN- $\gamma$ mRNA and $0.52(P$ $<0.001$ ) for IL-1 $\alpha$ mRNA (Table 2). In MPS-stimulated

Table 2. Pearson correlation coefficients comparing osteopontin gene expression to expression of key Th1 cytokines in peripheral blood mononuclear cells (PBMC) from periparturient dairy cows clinically infected with Mycobacterium avium ssp. paratuberculosis (MAP)

\begin{tabular}{lccc}
\hline & & \multicolumn{2}{c}{ Pearson correlation } \\
\cline { 3 - 4 } Item & Gene & Coefficient & $P$-value \\
\hline NS PBMC $^{1}$ & IFN- $\gamma$ & 0.53 & 0.0003 \\
& IL-1 $\alpha$ & 0.52 & 0.001 \\
MPS PBMC $^{2}$ & IFN- $\gamma$ & 0.76 & 0.0001 \\
& IL-12 & 0.50 & 0.004 \\
\hline
\end{tabular}

${ }^{1}$ Nonstimulated PBMC.

${ }^{2} \mathrm{PBMC}$ stimulated with a whole-cell sonicate of MAP.
PBMC isolated from clinical cows, the coefficient for Opn mRNA and IFN- $\gamma$ mRNA was $0.76(P<0.0001)$ and 0.50 for Opn mRNA and IL-12p35 mRNA $(P<$ 0.004). In contrast to the correlation of Opn to the Th1 cytokines in the clinically infected cows, there were no significant correlations for the Th2 cytokines (data not shown). Furthermore, there were not any significant correlations for either Th1 or Th2 cytokines for healthy control cows or subclinically infected cows (data not shown).

\section{Effects of Infection Status and Parturition on IFN- $\gamma$, IL-10, IL-4, and TGF- $\beta$ Secretion in Cell Culture Supernatants}

Production of IFN- $\beta$ by NS- (Figure 5A) and ConAstimulated (Figure 5B) PBMC tended to be greater ( $P$ $<0.08)$ in subclinical cows compared with the control cows. Secretion by subclinical cows increased $(P<0.05)$ from $-21 \mathrm{~d}$ to $+7 \mathrm{~d}$. Production of IFN- $\gamma$ by MPS-stimulated PBMC was greater $(P<0.01)$ in subclinical cows 


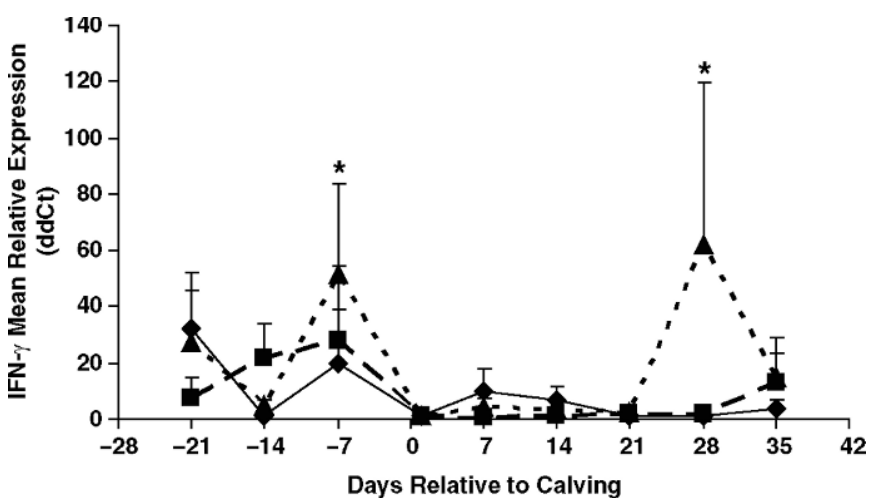

Figure 4. Interferon gamma gene expression by nonstimulated peripheral blood mononuclear cells isolated from whole blood of con-

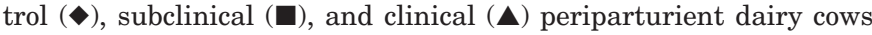
naturally infected with Mycobacterium avium ssp. paratuberculosis (parturition, $P<0.01$ ). Data are means $\pm \mathrm{SE}$. Significant differences within an infection group on a given day relative to $+1 \mathrm{~d}$ are represented by asterisks $(P<0.05)$.

compared with control cows and tended to be greater $(P<0.11)$ than clinical cows (Figure 5C). In subclinical cows, secretion increased $(P<0.002)$ from $-7 \mathrm{~d}(1.24$ $\mathrm{ng} / \mathrm{mL} \pm 0.4)$ to $+7 \mathrm{~d}$ postpartum $(4.2 \mathrm{ng} / \mathrm{mL} \pm 2.2)$.

The IL-10 secretion by NS PBMC was not affected by infection group or parturition (Figure $6 \mathrm{~A})$. However, secretion by subclinical cows increased $(P<0.01)$ from $-21 \mathrm{~d}$ to $+1 \mathrm{~d}$ and then declined $(P<0.02)$ to $+7 \mathrm{~d}$. Secretion also increased $(P<0.04)$ in control cows from $-14 \mathrm{~d}$ to $+7 \mathrm{~d}$. When stimulated with ConA, secretion was greater $(P<0.003)$ in subclinical cows compared with controls and tended to be greater $(P<0.09)$ than clinical cows (Figure 6B). A significant effect of parturition $(P<0.03)$ was also observed. Secretion of IL-10 in subclinical cows steadily increased $(P<0.0001)$ from $-21 \mathrm{~d}(0.72 \mathrm{U} \pm 0.2)$ to $+35 \mathrm{~d}(3.87 \mathrm{U} \pm 0.9)$. Production of IL-10 by MPS-stimulated PBMC was greater $(P<$ 0.04 ) in subclinical cows compared with controls (Figure $6 \mathrm{C}$ ). For all 3 infection groups (control, $P<0.04$; subclinical, $P<0.001$; and clinical, $P<0.05$ ), IL-10 secretion increased from $-21 \mathrm{~d}$ to $+14 \mathrm{~d}$.

Interleukin- 4 secretion by NS PBMC tended to be greater in clinical cows compared with controls (Figure 7A). There was an interaction of infection group and parturition on IL-4 secretion by PBMC $(P<0.01)$. This interaction was most likely due to an increase $(P<0.03)$ in secretion by clinical cows from $-21 \mathrm{~d}$ to $+1 \mathrm{~d}$. When cells were stimulated with ConA, an interaction of infection group and parturition was observed $(P<0.03$; Figure 7B). Interleukin- 4 secretion by MPS-stimulated PBMC was greater in clinical cows compared with control $(P<0.004)$ and subclinical cows $(P<0.04$; Figure 7C). Secretion of IL-4 by clinical cows increased $(P<$
A.

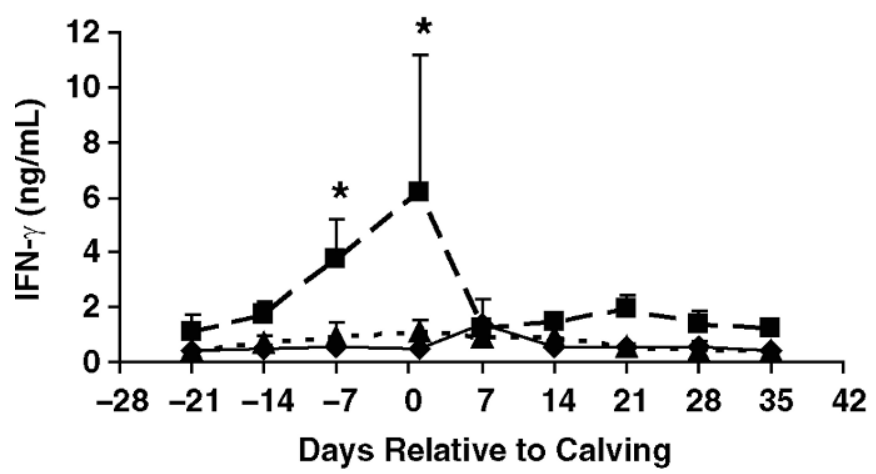

B.

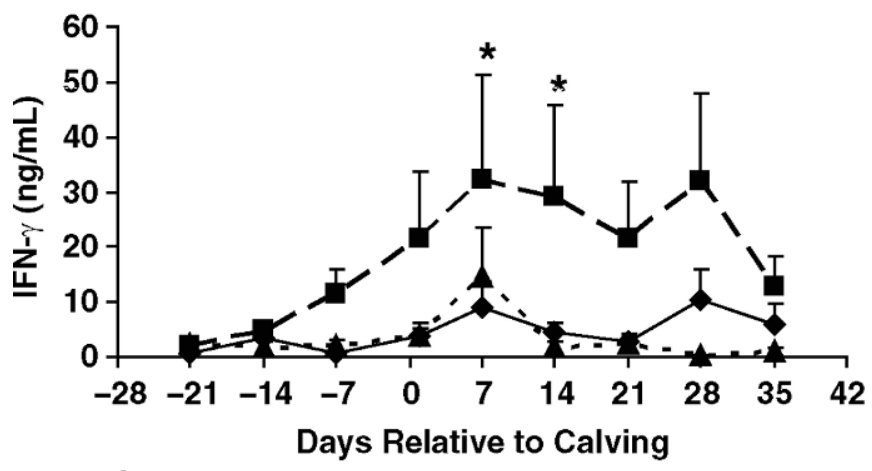

c.

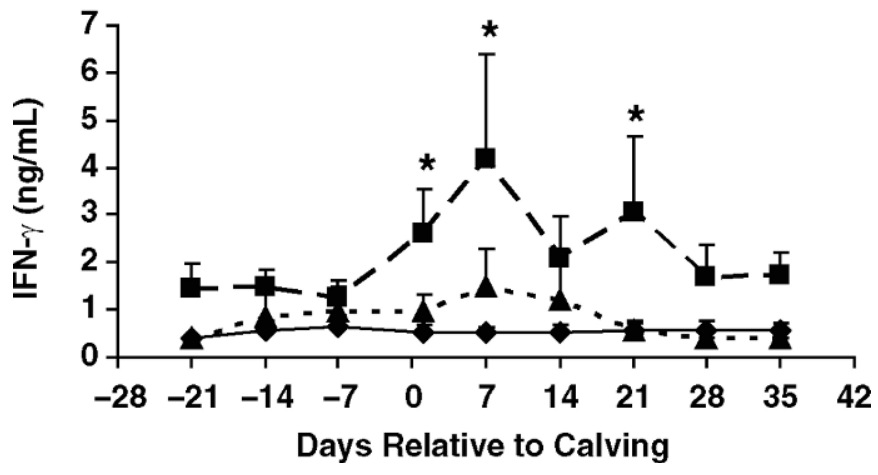

Figure 5. Interferon gamma secretion from peripheral blood mononuclear cells (PBMC) isolated from control ( ), subclinical ( $\square$ ), and clinical ( $\mathbf{\Delta})$ periparturient dairy cows naturally infected with $M y c o-$ bacterium avium ssp. paratuberculosis (MAP). Cells were incubated in RPMI for $24 \mathrm{~h}$. A) Nonstimulated PBMC. B) Concanavalin A PBMC. C) Peripheral blood mononuclear cells stimulated with a whole-cell sonicate of MAP. Data are means \pm SE. Significant differences between infection groups on a given day are represented by asterisks $(P<0.05)$.

$0.02)$ from $-21 \mathrm{~d}$ to $+7 \mathrm{~d}$, and control cow secretion increased $(P<0.04)$ from $-14 \mathrm{~d}$ to $+7 \mathrm{~d}$.

Secretion of TGF- $\beta$ by NS PBMC was not affected by infection group (Figure 8A); however, there was an overall effect of parturition $(P<0.01)$. There was a tendency for subclinical $(1,793.2 \mathrm{pg} / \mathrm{mL} \pm 35.3)$ and clinical $(1,795.7 \mathrm{pg} / \mathrm{mL} \pm 42.9)$ cows to have increased secre- 
A.

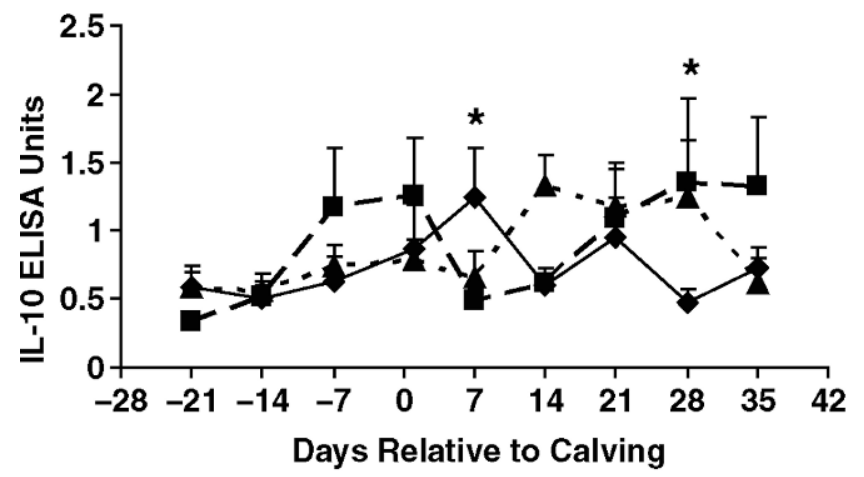

B.

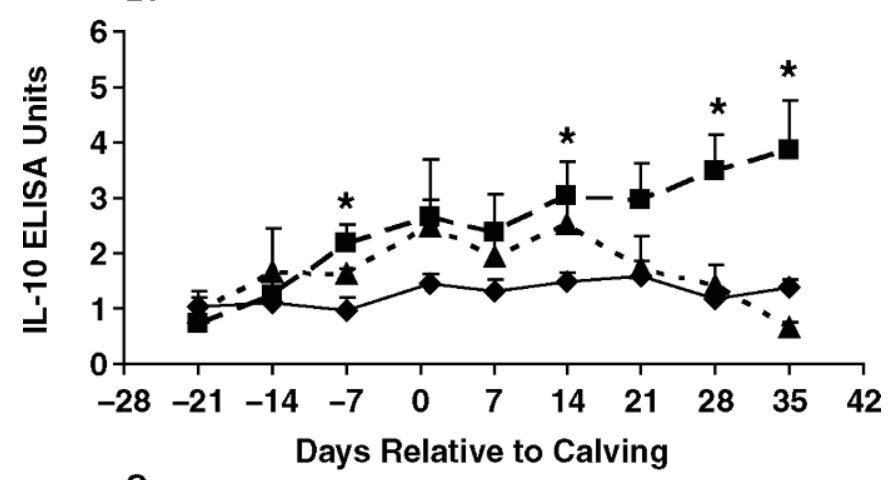

C.

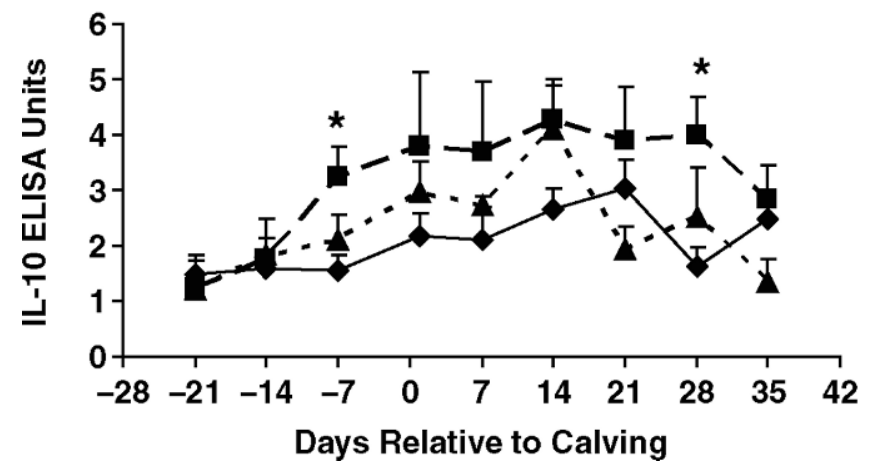

Figure 6. Interleukin-10 secretion from peripheral blood mononuclear cells (PBMC) isolated from control ( $\bullet$, subclinical $(\boldsymbol{\square})$, and clinical ( $\mathbf{\Delta})$ periparturient dairy cows naturally infected with Mycobacterium avium ssp. paratuberculosis (MAP). Cells were incubated in RPMI for $24 \mathrm{~h}$. A) Nonstimulated PBMC. B) Concanavalin A PBMC (parturition, $P<0.003$ ). C) Peripheral blood mononuclear cells stimulated with a whole-cell sonicate of MAP (parturition, $P<0.002$ ). Data are means \pm SE. Significant differences between infection groups on a given day are represented by asterisks $(P<0.05)$.

tion compared with controls $(1,708.8 \mathrm{pg} / \mathrm{mL} \pm 38.8)$. Secretion of TGF- $\beta$ by PBMC from subclinical cows increased $(P<0.0001)$ from $+1 \mathrm{~d}$ to $+21 \mathrm{~d}(1,639.2 \mathrm{pg} / \mathrm{mL}$ \pm 73.8 vs. $1,921.9 \mathrm{pg} / \mathrm{mL} \pm 75.2)$. Secretion by PBMC from clinical cows rapidly declined $(P<0.01)$ from -21 $\mathrm{d}$ to $+1 \mathrm{~d}$ and then increased $(P<0.04)$ from $+1 \mathrm{~d}$ to $+21 \mathrm{~d}(P<0.04)$. Stimulation of PBMC with ConA did not result in an overall effect of infection group or partu-
A.

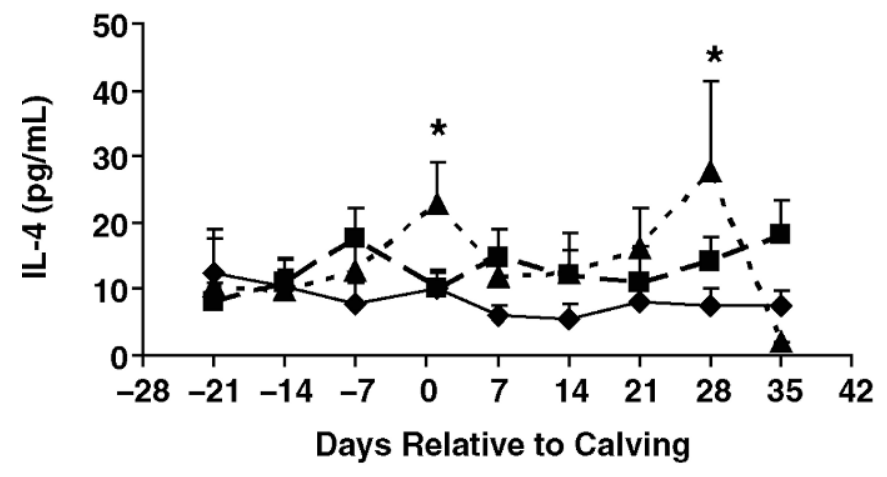

B.

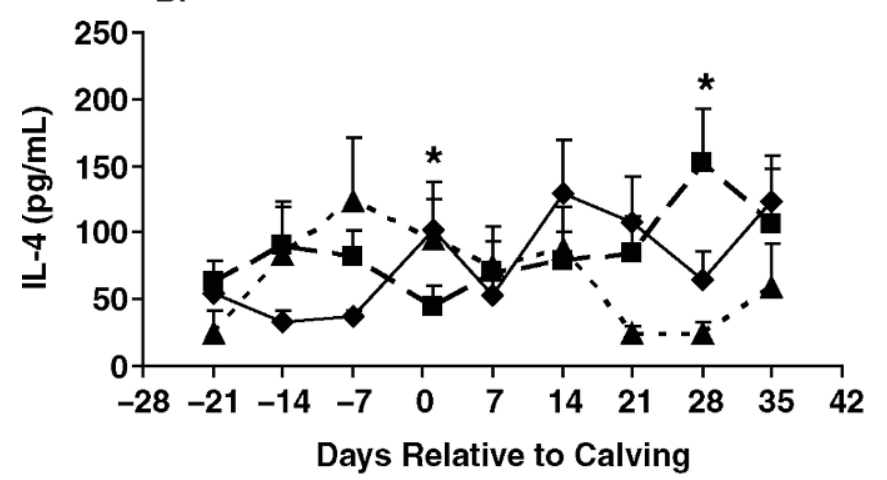

c.

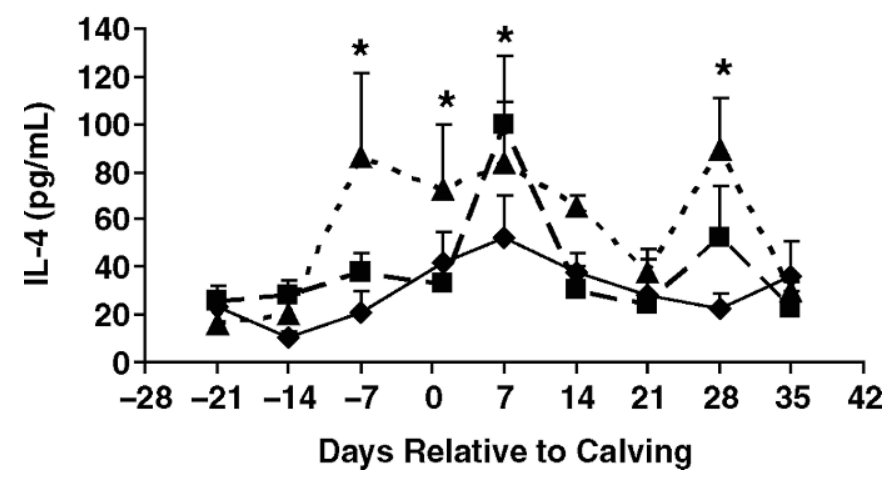

Figure 7. Interleukin-4 secretion from peripheral blood mononuclear cells (PBMC) isolated from control $(\bullet)$, subclinical $(\square)$, and clinical ( $\mathbf{\Delta}$ ) periparturient dairy cows naturally infected with $M y c o-$ bacterium avium ssp. paratuberculosis (MAP). Cells were incubated in RPMI for $24 \mathrm{~h}$. A) Nonstimulated PBMC (infection group and parturition interaction, $P<0.01$ ). B) Concanavalin A PBMC (infection group and parturition interaction, $P<0.03$ ). C) Peripheral blood mononuclear cells stimulated with a whole-cell sonicate of MAP (infection group, $P<0.05$; parturition effect, $P<0.0002$ ). Data are means \pm SE. Significant differences between infection groups on a given day are represented by asterisks $(P<0.05)$.

rition on TGF- $\beta$ secretion (Figure $8 \mathrm{~B}$ ). However, secretion from subclinical cows increased $(P<0.05)$ from -7 $\mathrm{d}$ to $+1 \mathrm{~d}$ and then declined until $+7 \mathrm{~d}$. Secretion from clinical cows declined $(P<0.05)$ from $-14 \mathrm{~d}$ to $+14 \mathrm{~d}$ $(1,795.9 \mathrm{pg} / \mathrm{mL} \pm 99.3$ vs. $1,590.4 \mathrm{pg} / \mathrm{mL} \pm 51.6)$. Secre- 
A.

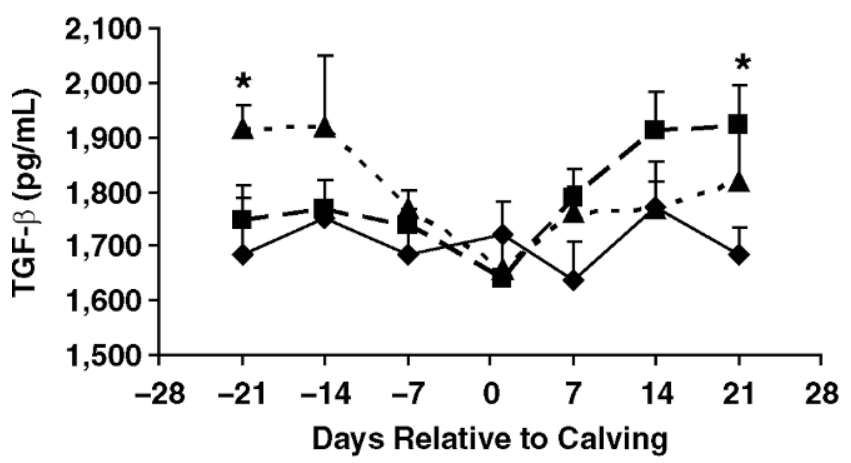

B.

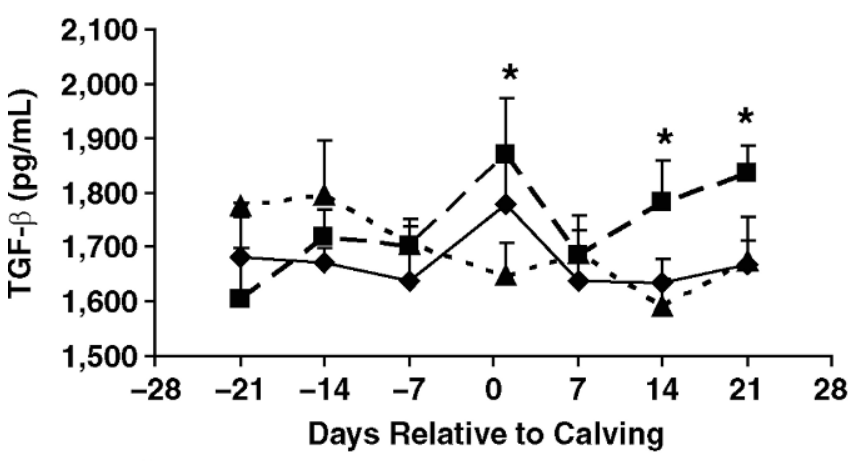

C.

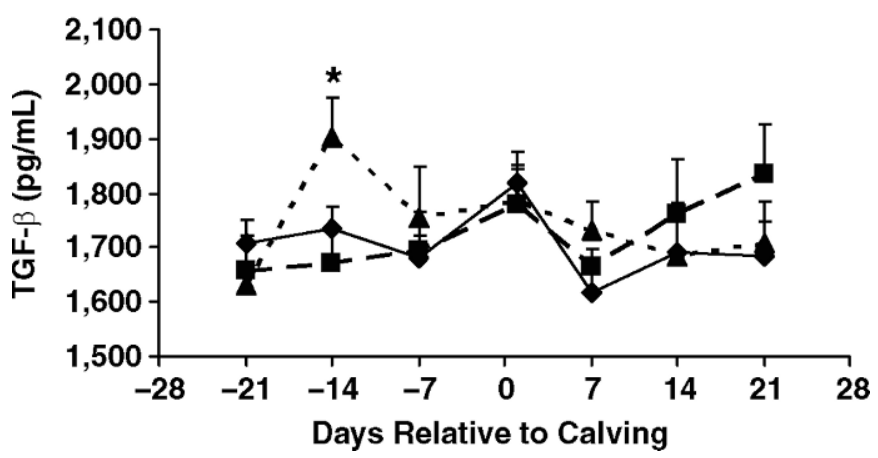

Figure 8. Transforming growth factor- $\beta$ (TGF- $\beta$ ) secretion from peripheral blood mononuclear cells (PBMC) isolated from control ( $\bullet$ ), subclinical ( $\mathbf{\square})$, and clinical $(\boldsymbol{\Delta})$ periparturient dairy cows naturally infected with Mycobacterium avium ssp. paratuberculosis (MAP). Cells were incubated in RPMI for $24 \mathrm{~h}$. A) Nonstimulated PBMC (parturition, $P<0.01$; infection group and parturition interaction, $P$ $<0.03$ ). B) Concanavalin A PBMC. C) Peripheral blood mononuclear cells stimulated with a whole-cell sonicate of MAP. Data are means \pm SE. Significant differences between infection groups on a given day are represented by asterisks $(P<0.05)$.

tion of TGF- $\beta$ by MPS-stimulated PBMC was not affected by infection group or parturition (Figure 8C).

\section{Opn Protein Analysis}

Osteopontin protein bands at $24,37,50$, and $62 \mathrm{kDa}$ were detected in the PBMC lysates of all animals by
A.
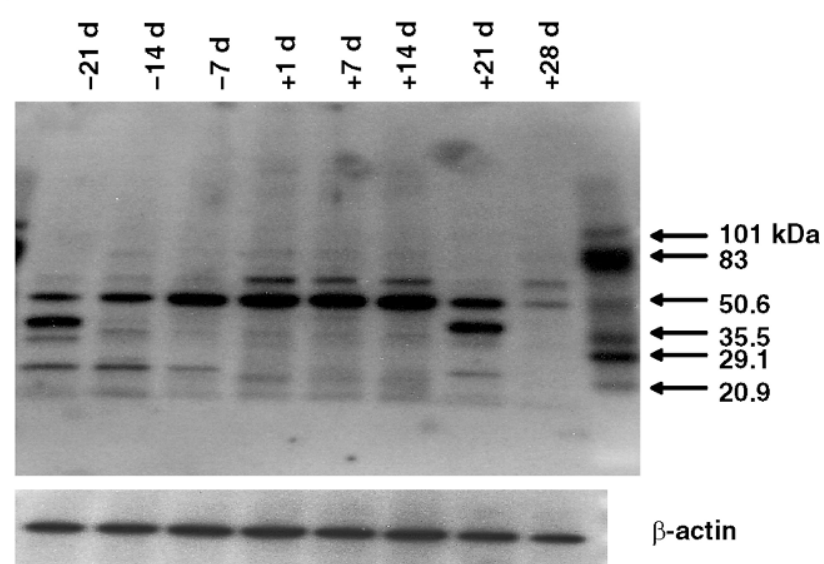

B. $\square$ Control $\square$ Subclinical $\square$ Clinical

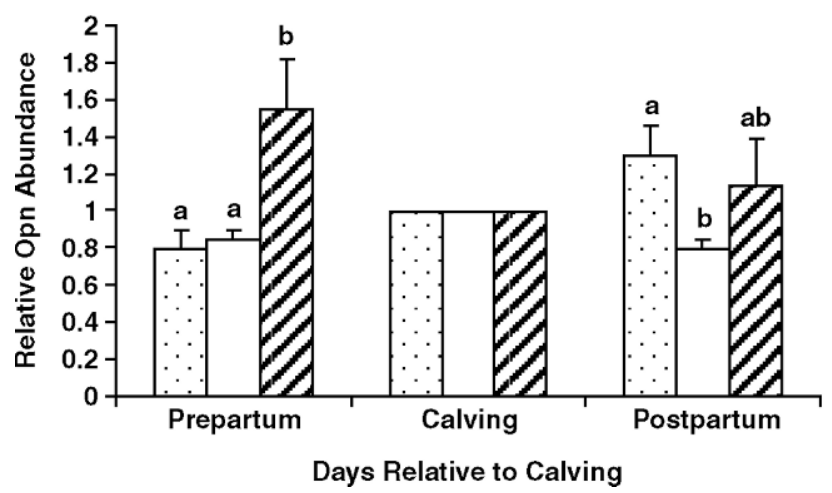

Figure 9. Osteopontin (Opn) protein expression in peripheral blood mononuclear cells isolated from whole blood of control, subclinical, and clinical periparturient dairy cows naturally infected with Mycobacterium avium ssp. paratuberculosis (MAP). A) Detection of Opn protein using Western blot analysis. Picture is of a representative blot from a subclinical MAP-infected periparturient dairy cow. B) Densitometric analysis of Opn relative abundance compared with calving (infection group and parturition interaction, $P<0.01$ ).

immunoblot analysis (Figure 9A). Purified bovine milk Opn was used as a standard and is identified as a single band at $60 \mathrm{kDa}$ (data not shown). The $50-\mathrm{kDa}$ protein was consistently the most intense of the 4 detected isomers. Therefore, to determine the relative abundance of Opn total protein, the $50-\mathrm{kDa}$ band was analyzed relative to $\beta$-actin. Sample dates were grouped into precalving ( $-21 \mathrm{~d},-14 \mathrm{~d}$, and $-7 \mathrm{~d}$ ), calving, and postcalving $(+7 \mathrm{~d},+14 \mathrm{~d},+21 \mathrm{~d}$, and $+28 \mathrm{~d})$. Analysis of the $50-\mathrm{kDa}$ Opn protein abundance by immunoblotting revealed an interaction of infection group and parturition $(P<0.01$; Figure 9B). The relative Opn abundance in PBMC from control cows increased throughout the sampling period $(P<0.02)$. The PBMC isolated from subclinical cows had increased Opn abundance at calv- 
ing that then declined during the postpartum period ( $P$ $<0.06)$.

\section{DISCUSSION}

Many calves become infected with MAP during the first 6 mo of life (Sweeney, 1996), typically through the fecal-oral route. Once infected, the cow often remains in the subclinical, or asymptomatic, stage of the disease until a period of heightened stress occurs. The subclinical stage of paratuberculosis is characterized by a Th1or cell-mediated immune response. In the current study, there was an increase in Opn expression in subclinical cows compared with control and clinical cows. This is important, because an increase in Opn expression supports the paradigm for strong Th1 host responses in subclinically infected dairy cows. One potential explanation for the increased Opn expression observed in subclinical animals is that the host immune system is responding to the intracellular MAP infection by promoting the polarization of Th1 CD4+ T cells. Increased Opn production by this cell type would promote the activation of macrophages, which in turn would induce the secretion of IL-12. Thus, creating a positive feedback loop to enhance the cell-mediated immune response typical to what is observed in subclinically infected cows. Osteopontin has been shown to enhance the production of Th1 cytokines, including IL-12 and TNF- $\alpha$ (Ashkar et al., 2000; Weber et al., 2002). Interleukin-12 regulates the balance of Th1 and Th2 cells by promoting the differentiation of naíve $\mathrm{T}$ cells to Th1 cells. Surprisingly, IL-12p35 expression was not affected by either MAP infection or parturition in this study. Previous reports have demonstrated that subclinical JD cows have greater expression and secretion of IFN- $\gamma$, another Th1 cytokine, compared with that of clinical cows (Stabel, 2000; Khalifeh and Stabel, 2004). Although IFN- $\gamma$ expression was not affected by infection status in the present study, consistent with the literature, subclinical cows did secrete greater quantities of IFN- $\gamma$ compared with control and clinical cows. Along with IFN- $\gamma$, TNF- $\alpha$ is involved in the early stages of mycobacterial infections by controlling bacterial proliferation (Appelberg, 1994). Interestingly, in this study, NS PBMC from clinical cows expressed more TNF- $\alpha$ than the controls or subclinical animals.

The importance of the relationship between Opn and the Th1 cytokines was further emphasized when assessing the Pearson correlation data. There was a positive correlation between Opn expression and the expression of the Th1 cytokines IL-12 and IFN- $\gamma$ in clinically infected cattle. Osteopontin has been linked to enhanced production of IL-12 (Ashkar et al., 2000).
Typically in MAP infection, as the disease progresses from a subclinical to a clinical stage, there is a transition from the Th1 to Th2 immune response. This transition has been documented by the upregulation of IL10 and TGF- $\beta$ in ileal tissues from clinical JD cows (Khalifeh and Stabel, 2004). In addition, Coussens et al. (2004) reported lower expression of IL-4 for both subclinically and clinically infected cows as compared with control cows after stimulation of PBMC with MAP, similar to results presented here. However, in the present study, IL-4 secretion by MPS-stimulated PBMC was greater in clinical cows compared with the control and subclinical cows. This finding is consistent with the transition from a Th1 to Th2 response occurring in clinical JD cows. Transforming growth factor- $\beta$ and Th2 cytokines work synergistically to inhibit the secretion of IFN- $\gamma$ and the activation of macrophages. However, Opn is capable of inhibiting the expression of Th2 cytokines. Osteopontin gene expression by NS PBMC isolated from clinical cows was less than that of the subclinical cows, and expression declined by 7 -fold the week leading up to parturition. A potential consequence of reduced Opn expression may be a decline in the cellmediated immune response and a subsequent increase in humoral immunity. Mice deficient in Opn expression had increased IL-10 production and decreased macrophage function (Ashkar et al., 2000). In the current study, TGF- $\beta$ secretion for both subclinical and clinical dairy cows rapidly increased at calving and continued to increase until $+21 \mathrm{~d}$. This increase in TGF- $\beta$ at calving in subclinical cows mirrored a decline in Opn expression.

Published reports indicate that the expression and secretion of IFN- $\gamma$ begins to decline as parturition approaches (Ishikawa et al., 1994; Shafer-Weaver et al., 1999). The decline in Opn as parturition approached further supports the classification of Opn as a Th1 cytokine. In late gestation, there is a shift in the CD4 ${ }^{+}$ T-cell population supporting a Th2 response in healthy dairy cows (Shafer-Weaver et al., 1999). In the present study, IL-10 secretion from all groups, regardless of infection status, increased during the last week of gestation. Furthermore, clinical cows showed increased expression of IL- 4 from $-21 \mathrm{~d}$ to $+7 \mathrm{~d}$ postcalving. Together, these results support a Th2 response during the immediate prepartum and postpartum period.

This is the first study to report protein expression of Opn in PBMC isolated from Holstein dairy cows. Using immunoblotting techniques, we identified 4 isomers of the Opn protein at $24,37,50$, and $62 \mathrm{kDa}$. The $50-\mathrm{kDa}$ protein was dominant for all animals, but there was extensive cow-to-cow variation in the 24-, 37-, and 62$\mathrm{kDa}$ isomers. Multiple isomers of the Opn protein are not uncommon in tissues. Three Opn isomers at 60, 40, 
and $22 \mathrm{kDa}$ were identified in the testicular parenchyma of the bull reproductive tract (Erikson et al., 2007), and using an antibody to bovine milk Opn, Kimmins et al. (2004) identified Opn proteins at 70, 45, 34, and $24 \mathrm{kDa}$ in cyclic bovine endometrium. It has been suggested that the lower molecular weight isomers (20 to $25 \mathrm{kDa}$ ) are part of the $\mathrm{COOH}$-terminal portion of Opn (Zhang et al., 1990). There is a subset of T cells that secrete a $40-\mathrm{kDa}$ Opn protein that is capable of activating B cells to produce Ig (Leibson et al., 1981). Relative Opn levels from the PBMC of control cows increased throughout the sampling period. Subclinical cows had an increase in abundance at calving and then showed a decline during the postpartum period. The increase in Opn at calving was not consistent with a decline in Th1 cytokines as parturition approached. One explanation for the postpartum Opn decline may be that these animals were transitioning to the clinical stage of the disease and were beginning to exhibit a Th2 immune response. The increase in Opn in control cows during the postpartum period is consistent with an increase in Th1 cytokines as lactation progresses.

Despite a lack of studies evaluating the role of Opn in MAP infection, there are an extensive number of human and murine studies documenting interactions of other mycobacterial infections and Opn. When Opn knockout mice were challenged with $10^{7} \mathrm{cfu}$ of $M$. bovis bacillus Calmette-Guerin, the mutant mice had more severe infection, heavier bacterial loads, and greater granuloma burdens compared with the controls (Nau et al., 1999). Another study utilizing Opn knockout mice demonstrated a 95 and $90 \%$ decrease in IL-12 and IFN$\gamma$ secretion, respectively, compared with the wild-type controls (Ashkar et al., 2000). These knockout studies present convincing data that establish the importance of Opn involvement in the immediate host immune response to mycobacterial challenges.

Despite reports supporting the ability of Opn to influence T-cell polarization to a Th1 response, a small pool of literature exists that challenges this model. A recent study reported the ability of Opn knockout mice to respond to an experimental infection with the influenza virus and vaccinia virus (Abel et al., 2005). Interestingly, Opn knockout mice produced similar quantities of IFN- $\gamma$ compared with the control mice. Further, viral clearance, lung inflammation, and recruitment of effector $\mathrm{T}$ cells to the lung were not affected by the Opn deficiency, suggesting that Th1-mediated immune responses could be induced in the absence of Opn. Further, Potter et al. (2002) reported that Opn deficiency in mice did not have an effect on tissue colonization with spirochetes after experimental infection with Borrelia burgdorferi. These results contrast with other studies that have demonstrated a role for Opn in eliciting Th1 immune responses (Nau et al., 1999; Ashkar et al., 2000) and may represent differences due to the nature of the pathogen (i.e., viral vs. bacterial and extracellular vs. intracellular). Regardless, these data highlight the need for future experiments to further understand the mechanism of Opn in the bovine immune system and, more specifically, the role of Opn in the mediation of infection with an intracellular pathogen such as MAP.

\section{CONCLUSIONS}

This study presents the first analysis of Opn gene and protein expression in periparturient dairy cows naturally infected with MAP. The results indicate that Opn expression in dairy cows is modulated during natural MAP infection and by the periparturient period. Furthermore, this is the first evidence of Opn expression in PBMC of healthy and MAP-infected dairy cows. Our data provide an indication that Opn may be a key regulator in MAP infection.

\section{ACKNOWLEDGMENTS}

We thank Megan Parlett (NADC) for technical assistance and Norm Tjelmeland and Paul Amundson (NADC) for outstanding animal care.

\section{REFERENCES}

Abel, B., S. Freigang, M. F. Bachmann, U. Boschert, and M. Kopf. 2005. Osteopontin is not required for the development of Th1 responses and viral immunity. J. Immunol. 175:6006-6013.

Agnholt, J., J. Kelsen, L. Schack, C. L. Hvas, J. F. Dahlerup, and E. S. Sorensen. 2007. Osteopontin, a protein with cytokine-like properties, is associated with inflammation in Chrohn's disease. Scand. J. Immunol. 65:453-460.

Appelberg, R. U. I. 1994. Protective role of interferon gamma, tumor necrosis factor alpha and interleukin-6 in Mycobacterium tuberculosis and $M$. avium infections. Immunobiology 191:520-525.

Ashkar, S. A., G. F. Weber, V. Panoutsakopoulou, M. E. Sanchirico, M. Jansson, S. Zawaideh, S. R. Rittling, D. T. Denhardt, M. J. Glimcher, and H. Cantor. 2000. Eta-1 (osteopontin): An early component of type-1 (cell-mediated) immunity. Science 287:4860-4864.

Atkins, K., J. E. Berry, W. Z. Zhang, J. F. Harris, A. F. Chambers, R. U. Simpson, and M. J. Somerman. 1998. Coordinate expression of OPN and associated receptors during monocyte/macrophage differentiation of HL-60 cells. J. Cell. Physiol. 175:229-237.

Coussens, P. M., N. Verman, M. A. Coussens, M. D. Elftman, and A. M. McNulty. 2004. Cytokine gene expression in peripheral blood mononuclear cells and tissues of cattle infected with Mycobacterium avium subsp. paratuberculosis: Evidence for an inherent proinflammatory gene expression pattern. Infect. Immun. 72:1409-1422.

Denhardt, D. T., and X. Guo. 1993. Osteopontin: A protein with diverse functions. FASEB J. 7:1475-1482.

Erikson, D. W., A. L. Way, D. A. Chapman, and G. J. Killian. 2007. Detection of osteopontin on Holstein bull spermatozoa in cauda epididymal fluid and testis homogenates, and its potential role in bovine fertilization. Reproduction 133:909-917.

Ishikawa, H., T. Shirahata, and K. Hasegawa. 1994. Interferon- $\gamma$ production of mitogen stimulated peripheral lymphocytes in perinatal cows. J. Vet. Med. Sci. 56:735-738. 
Kawamura, K., K. Iyonaga, H. Ichiyasu, J. Nagano, M. Suga, and Y. Sasaki. 2005. Differentiation, maturation, and survival of dendritic cells by osteopontin regulation. Clin. Diagn. Lab. Immunol. 12:206-212.

Khalifeh, M. S., and J. R. Stabel. 2004. Upregulation of transforming growth factor-beta and interleukin-10 in cows with clinical Johne's disease. Vet. Immunol. Immunopathol. 99:39-46.

Kimmins, S., H. C. Lim, and L. A. MacLaren. 2004. Immunohistochemical localization of integrin alpha $\mathrm{V}$ beta 3 and osteopontin suggests that they do not interact during embryo implantation in ruminants. Reprod. Biol. Endocrinol. 2:19-32.

Laemmli, U. K. 1970. Cleavage of structural proteins during the assembly of the head of bacteriophage T4. Nature 227:680-685.

Lampe, M. A., R. Patarca, M. V. Iregui, and H. Cantor. 1991. Polyclonal $\mathrm{B}$ cell activation by the Eta-1 cytokine and the development of systemic autoimmune disease. J. Immunol. 147:2902-2906.

Leibson, H. J., P. Marrack, and J. W. Kappler. 1981. B cell helper factors. I. Requirements for both interleukin 2 and another 40,000 mol wt factor. J. Exp. Med. 154:1681-1693.

Liang, C. J., H. E. Ives, C. M. Yang, and Y. H. Ma. 2008. 20-HETE inhibits the proliferation of vascular smooth muscle cells via transforming growth factor-beta. J. Lipid Res. 49:66-73.

Livak, K. J., and T. D. Schmittgen. 2001. Analysis of relative gene expression data using real-time quantitative PCR and the 2(delta delta $\mathrm{C}(\mathrm{t})$ ) method. Methods 25:402-408.

Nau, G. J., G. L. Chupp, J. Emile, E. Jouanguy, J. S. Berman, J. Casanova, and R. A. Young. 2000. Osteopontin expression correlates with clinical outcome in patients with mycobacterial infection. Am. J. Pathol. 157:37-42

Nau, G. J., P. Guilfoile, G. L. Chupp, J. S. Berman, S. J. Kim, H. Kornfeld, and R. A. Young. 1997. A chemoattractant cytokine associated with granulomas in tuberculosis and silicosis. Proc. Natl. Acad. Sci. USA 94:6414-6419.

Nau, G. J., L. Liaw, G. L. Chupp, J. S. Berman, B. L. M. Hogan, and R. A. Young. 1999. Attenuated host resistance against Mycobacte- rium bovis $\mathrm{BCG}$ infection in mice lacking osteopontin. Infect. Immun. 67:4223-4230.

O'Regan, A. W., J. M. Hayden, and J. S. Berman. 2000. Osteopontin augments CD3-mediated interferon- $\gamma$ and CD40 ligand expression by T cells, which results in IL-12 production from peripheral blood mononuclear cells. J. Leukoc. Biol. 68:495-502.

Pollack, S. B., P. A. Linnemeyer, and S. Gill. 1994. Induction of osteopontin mRNA expression during activation of murine NK cells. J. Leukoc. Biol. 55:398-400.

Potter, M. R., S. R. Rittling, D. T. Denhardt, R. J. Roper, J. H. Weis, C. Teuscher, and J. J. Weiss. 2002. Role of osteopontin in murine Lyme arthritis and hose defense against Borrelia burgdorferi. Infect. Immun. 70:1372-1381.

Schmittgen, T. D., and B. A. Zakrajsek. 2000. Effect of experimental treatment on housekeeping gene expression: Validation by realtime, quantitative RT-PCR. J. Biochem. Biophys. Methods 46:69-81.

Shafer-Weaver, K. A., C. M. Corl, and L. M. Sordillo. 1999. Shifts in bovine CD4+ subpopulations increase T-helper-2 compared with T-helper-1 effector cells during the postpartum period. J. Dairy Sci. 82:1696-1706.

Stabel, J. R. 1997. An improved method for cultivation of Mycobacterium paratuberculosis from bovine fecal samples and comparison to three other methods. J. Vet. Diagn. Invest. 9:375-380.

Stabel, J. R. 2000. Cytokine secretion by peripheral blood mononuclear cells from cows infected with Mycobacterium paratuberculosis. Am. J. Vet. Res. 61:754-760.

Sweeney, R. W. 1996. Transmission of paratuberculosis. Vet. Clin. North Am. Food Anim. Pract. 12:305-312.

Weber, G. F., S. Zawaideh, S. Hikita, V. A. Kumar, H. Cantor, and S. Ashkar. 2002. Phosphorylation-dependent interaction of osteopontin with its receptors regulates macrophage migration and activation. J. Leukoc. Biol. 72:752-761.

Zhang, Q., C. Domenicucci, H. A. Goldberg, J. L. Wrana, and J. Sodek. 1990. Characterization of fetal porcine bone sialoproteins, secreted phosphoprotein I (SPPI, osteopontin), bone sialoprotein, and a 23-kDa glycoprotein. J. Biol. Chem. 265:7583-7589. 